\title{
EFFECTS OF A FACEBOOK PROFILE DEVOTED TO DRUG USE IN PREGNANCY ON THE DISCOVERY OF INAPPROPRIATE DRUG USE BY PREGNANT FEMALES IN THE FORMER YUGOSLAV REPUBLICS
}

Slobodan M. Jankovic ${ }^{1}$, Marija Babic ${ }^{1}$, Barudzic Nevena ${ }^{1}$, Jelena Bogojevic ${ }^{1}$, Obrad Vasic $^{1}$, Marija Vucicevic ${ }^{1}$, Miona Dragojevic ${ }^{1}$, Aleksadra Ivanovic ${ }^{1}$,

Aleksandra Ignjatovic ${ }^{1}$, Ana Markovic ${ }^{1}$, Jelena Milovanovic ${ }^{1}$, Jovana Miloradovic ${ }^{1}$, Sladjana Miladinovic ${ }^{1}$, Milica Petrovic ${ }^{1}, Z^{2}$ ora Pecelj$^{1}$, Jelena Radivojevic ${ }^{1}$, Jelena Rajcic ${ }^{2}$, Selena Rancic ${ }^{1}$, Ana Ristic ${ }^{1}$, Ivana Rudnjanin ${ }^{1}$, Katarina Savic ${ }^{1}$, Marija Spasic ${ }^{1}$, Tatjana Stankovic ${ }^{1}$, Stevan Stasevic ${ }^{1}$, Milos Stevanovic ${ }^{1}$, Sladjan Stojilkovic ${ }^{1}$, Marina Trunic ${ }^{1}$, Milica Scekic ${ }^{1}$ ${ }^{1}$ Medical Faculty, University of Kragujevac, Kragujevac, Serbia ${ }^{2}$ Independent Researcher

\section{DOPRINOS FEJSBUK PROFILA POSVEĆENOG KORIŠĆENJU LEKOVA U TRUDNOĆI OTKRIVANJU NEODGOVARAJUĆE UPOTREBE LEKOVA U BIVŠIM JUGOSLOVENSKIM REPUBLIKAMA}

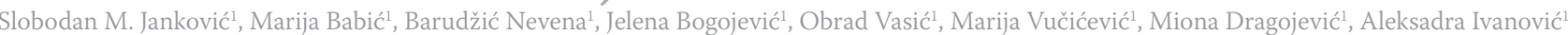

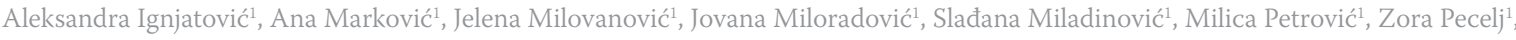

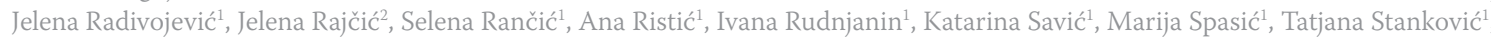
Stevan Stašević1, Miloš Stevanovići ${ }^{1}$, Slađan Stojilković1, Marina Trunić1, Milica Šćekić ${ }^{1}$

${ }^{1}$ Medicinski fakultet Univerziteta u Kragujevcu, Kragujevac, Srbija Nezavisni istraživač

\section{SHORT TITLE: \\ INAPPROPRIATE DRUG USE IN PREGNANCY AND FACEBOOK}

\section{ABSTRACT}

Background. Although online social networking is increasingly used for medical purposes, studies investigating drug use among pregnant females by means of online networks are lacking.

Objective. The aim of our study was to investigate the extent of inappropriate drug use among pregnant women by creating a Facebook profile and using it as a tool for interacting with pregnant women.

Methods. A Facebook profile titled "Preserve babies from drugs" was created and maintained by a group of fourth-year pharmacy students for 3 months. Introductory educational material about the principles of drug use in pregnancy, information about health facilities offering counselling about pregnancy, information about a clinical pharmacology department that offered counselling and an open-ended questionnaire were posted in the "Notes" section of the Facebook profile.

Results. Of 239 registered pregnant "friends" of the profile who received the questionnaire from the investigators, 93 responded (39\%). Among the respondents, 50 pregnant women (53.8\%) reported taking medication(s) during their current pregnancy, and 42 of the respondents reported using one or more drugs improperly. The most frequently used drugs were multivitamin and multi-mineral preparations, oral antibiotics, parenteral progesterone and benzodiazepines.

Conclusions. The Facebook profile devoted to drug use in pregnancy could be a useful adjunct to efforts by official health care institutions to identify inappropriate drug use and educate pregnant women appropriately.

Keywords. Facebook, online social networking, drugs, pregnancy

\section{SAŽETAK}

Uvod. Iako se socijalno umrežavanje na internetu sve više koristi u medicinske svrhe, istraživačke studije putem internet mreža koje se bave upotrebom lekova kod trudnica nedostaju.

Cilj. Cilj našeg rada je bila analiza slučajeva neodgovarajuće upotrebe lekova medu trudnicama koji mogu biti otkriveni stvaranjem fejsbuk profila sa odgovarajućim informacijama.

Metode. Grupa studenata četvrte godine farmacije formirala je fejsbuk profil pod nazivom "Cuvajmo bebe od lekova" koji je bio aktivan 3 meseca. U delu „Beleške" ovog profila unete su informacije o zdravstvenim ustanovama koje nude savetovanje trudnica, edukativni materijal o principima upotrebe lekova u trudnoći $i$ otvoreni upitnik.

Rezultati. Od 239 prijavljenih trudnica, "prijatelja“ našeg profila koje su dobile upitnik od istraživača, 93 (39\%) njih je odgovorilo. Medu ispitanicama bilo je 50 (53.8\%) trudnica koje su uzimale lekove tokom trudnoće. Čak 42 trudnice koristile su jedan ili više lekova na neodgovarajuć način. Najčešće nepravilno korišćeni lekovi bili su multivitaminski $i$ multi-mineralni preparati, oralno primenjeni antibiotici, parenteralno primenjeni preparati estrogena kao i benzodiazepini.

Zaključak. Fejsbuk profil posvećen upotrebi lekova u trudnoći može da bude korisna dodatna mera uz napore zvaničnih zdravstvenih ustanova za otkrivanje slučajeva nepravilog korišćenjag lekova kao i za informisanje trudnica.

Ključne reči. Fejsbuk, socijalno umrežavanje, lekovi, trudnoća 


\section{INTRODUCTION}

Online social networking is increasingly being used for medical purposes. Patients with the same disorder or similar disorders frequently use online networks to exchange their experiences with new therapies or share emotional support [1]. Facebook is the most frequently used online network, followed by MySpace and Twitter [2]. Recently, Facebook has been used to investigate beliefs and attitudes associated with prescription drug misuse among students [3] and to increase spontaneous reporting of adverse drug reactions [4]. Such interventions are cheap and reasonably effective; just a few working days may reveal dozens of adverse drug reactions [4].

We are not aware of any previous studies investigating drug use among pregnant women by means of online networks. Pregnant women frequently use over-the-counter preparations, but, in the majority of cases, the safety of these preparations during pregnancy for both the mother and child is not supported by evidence [5]. Even when prescribed, drugs used in pregnancy may belong to categories with known teratogenic or toxic foetal effects in a significant percentage of the patients (up to 4\%). Self-medication increases the likelihood of inappropriate drug use in pregnancy [6]. Appropriate information offered to pregnant women about the effects of drugs on pregnancy and the foetus and information gathered from pregnant women about drug use may help to identify or prevent inappropriate drug use.

The aim of our study was to investigate the extent of inappropriate drug use among pregnant women by creating a Facebook profile to interact with pregnant women.

\section{METHOD}

\section{Building the profile}

A Facebook profile titled "Preserve babies from drugs" (in the Serbian language) was created on February 24, 2011 by a group of fourth-year pharmacy students and their professor of clinical pharmacy (investigators: 26 students + professor) from the Medical Faculty, University of Kragujevac, Serbia (available at http://www.facebook.com/home. php\#!/profile.php?id=100002117414536). The profile was active until June 5, 2011.

Introductory educational material about the principles of drug use in pregnancy (2 pages), information about health facilities offering pregnancy counselling (3 facilities), information about a clinical pharmacology department offering counselling for drug use in pregnancy and an open-ended questionnaire for pregnant women targeting their drug history during pregnancy were posted in the "Notes" section of the Facebook profile. All written materials were created by the investigators. An explanation of the purpose of the profile (identifying inappropriate drug use in pregnancy and providing information about counselling) was posted on the "Info" section of the profile. Motivating photographs and drawings about life during pregnancy and the mother-child relationship were posted in the "Photos" section of the profile.

\section{Linking the profile}

The profile "Preserve babies from drugs" was linked to the following Facebook profiles and groups dealing with pregnancy: Zdrava trudnoća, Klub trudnica i mladih mama, Trudnoća, YuMama, BEBAC.com, Super beba, Udruženje RODITELJ, Dnevnik bebe, Ringeraja porodični portal - www.Ringeraja.rs, Roditelji.hr, e-beba, Moje Dijete, BHBebe.com - Bosansko-hercegovački porodični portal, Yoga za trudnice, mame i bebe - Shakti mama, Mamino Sunce, NajboljaMamaNaSvetu.com, Škola za trudnice, \& Mame \& Bebe \& Trudnice, KLUB MAMA SA FB-a, Moja trudnoća, MojaBeba, RoditeljSrbija, Dani beba, and djete i trudnica. Web pages devoted to pregnancy were also visited, and, after registration, information about the Facebook profile "Preserve babies from drugs" was left on these pages (http://www. trudnoca.net/forum/, http://www.ringeraja.rs/forum/ tt.asp?forumID=204, http://mameibebe.biz.hr/phpBB2/ viewforum.php?f=35).

\section{Recruiting pregnant women}

Pregnant women with their own profiles on Facebook were recruited by the investigators using both a joint profile ("Preserve babies from drugs") and the investigators' personal profiles. To reach as many pregnant women as possible, the information was spread by "friends" of the "Preserve babies from drugs" profile.

The recruitment of pregnant women was enhanced by posting flyers with information on the "Preserve babies from drugs" profile for patients of primary care health facilities that regularly offer pregnancy counselling in 11 Serbian towns (20 to 40 flyers posted on one occasion per town).

\section{Establishing contact with pregnant women}

The pregnant women who were recruited by the previously mentioned methods became "friends" of the "Preserve babies from drugs" profile. These women were then approached by investigators in three ways: by e-mail, by Facebook "Messenger" or by chat. The pregnant women were sent a questionnaire about their medical history before and during their pregnancy and about the ways they informed themselves about pregnancy. The subjects responded to the questionnaire by e-mail, Facebook "Messenger" or chat (with the help of the investigators).

The investigators did not advise the respondents about drug use during pregnancy, but they directed these women to the Clinical Pharmacology Department of the Clinical Center in Kragujevac to receive additional information.

\section{Processing the data}

After collecting the completed questionnaires, the responses were coded and entered in an SPSS workbook (version 18). Descriptive statistics were identified from the data using frequencies, measures of central tendency and measures of variability. 


\section{RESULTS}

During the study period, 239 registered "friends" of the profile received the questionnaire from the investigators, and 93 pregnant women responded to the questionnaire (39\% response rate). The characteristics of the respondents are shown in Table 1. Among the respondents, 50 pregnant women took medication(s) during their current pregnancy (53.8\%). The characteristics of the medications and therapeutic regimens are shown in Table 2. After comparing prescribed drugs and those used on the patient's own initiative with the respondents' stated reasons for taking drugs and current recommendations for drug use during pregnancy, two experts (clinical pharmacology specialists) from the Clinical Pharmacology Department of the Clinical Center in Kragujevac decided whether the drug use was justified. The results of their analysis are shown in Table 3.

\section{DISCUSSION}

In our study, a Facebook profile devoted to the use of drugs in pregnancy proved useful for identifying pregnant women who used drugs improperly. Of 50 pregnant women who reported using drugs, 42 used one or more drugs improperly. The drugs with the most frequent improper use were multivitamin and multi-mineral preparations (used for supplementation without a clear reason), oral antibiotics, parenteral progesterone and benzodiazepines. Although multivitamin and multi-mineral preparations (in recommended daily doses) do not cause harm to pregnant women (except for unnecessary costs), broad-spectrum antibiotics can cause diarrhoea. Progesterone is ineffective for treating threatened miscarriage [7], and both progesterone $[8,9]$ and benzodiazepines are suspected to have teratogenic potential and are not recommended for use in pregnancy without clear indication $[10,11]$.

The majority of pregnant women connected to our profile were inexperienced in drug use during pregnancy $(68.8 \%$ of the respondents were in their first pregnancy). Only two of the respondents had a child with congenital anomalies in their families. However, $92 \%$ of the medications were prescribed by physicians, making physicians responsible for inappropriate prescribing in pregnancy. Visits to counselling services for pregnant women were not helpful for avoiding prescribing errors because more than $60 \%$ of the women visited such services regularly. The findings on inadequate prescribing and advising in pregnancy were further confirmed by the low percentage $(24.7 \%)$ of pregnant women who were taking prophylactic doses of folic acid, an intervention that is considered a standard of care in pregnancy [12]. In addition to the obvious need for additional education of health workers regarding drug use in pregnancy, it seems that establishing and maintaining profiles devoted to drugs in pregnancy on social networks such as Facebook is a useful intervention that may not only help to identify inappropriate drug use during pregnancy but may also provide a communication channel through which pregnant women can receive important information about drugs and prevent the adverse consequences of inappropriate drug use.

\begin{tabular}{|l|l|}
\hline CHARACTERISTIC & VALUE \\
\hline Age of the respondents (mean \pm standard deviation) & $27.3 \pm 5.0$ years \\
\hline Country of residence (Serbia/other ex-YU country/other European country) & $83 / 7 / 3(\mathbf{8 9 . 2 \% / 7 . 7 \% / 3 . 3 \% )}$ \\
\hline City or town of residence & 32 different cities or towns \\
\hline $\begin{array}{l}\text { Level of education (elementary school/high school/higher } \\
\text { vocational school/bachelor's/master's or specialist) }\end{array}$ & $2 / 60 / 11 / 13 / 7$ \\
\hline Employed (yes/no) & $\mathbf{2 . 2 \% / 6 4 . 5 \% / 1 1 . 8 \% / 1 4 \% / 7 . 5 \% ) ~}$ \\
\hline Working during pregnancy (yes/no) & $34 / 59(\mathbf{3 6 . 6 \% / 6 3 . 4 \% )}$ \\
\hline Marital status (married/widowed/single) & $17 / 76(\mathbf{1 8 . 3 \% / 8 1 . 7 \% )}$ \\
\hline Number of children (0/1/2) & $83 / 1 / 9(89.2 \% / 1.1 \% / 9.7 \%)$ \\
\hline Order of current pregnancy (first/second/third/fourth) & $66 / 20 / 7(\mathbf{7 1 \% / 2 1 . 5 \% / 7 . 5 \% )}$ \\
\hline Week of current pregnancy (mean \pm standard deviation) & $64 / 17 / 8 / 4(68.8 \% / 18.3 \% / 8.6 \% / 4.3 \%)$ \\
\hline Complications of pregnancy (yes/no) & $23.7 \pm 8.9$ \\
\hline Chronic disease (yes/no) & $14 / 79(\mathbf{1 5 . 1 \% / 8 4 . 9 \% )}$ \\
\hline Allergies (yes/no) & $8 / 85(\mathbf{8 . 6 \% / 9 1 . 4 \% )}$ \\
\hline Gestational diabetes (yes/no) & $24 / 69(\mathbf{2 5 . 8 \% / 7 4 . 2 \% )}$ \\
\hline Taking medication during previous pregnancy (yes/no) & $3 / 90(3.2 \% / 96.8 \%)$ \\
\hline Previous spontaneous abortion (yes/no) & $16 / 77(\mathbf{1 7 . 2 \% / 8 2 . 8 \% )}$ \\
\hline Cause of spontaneous abortion (trauma/anomaly/unknown) & $9 / 84 \mathbf{( 9 . 7 \% / 9 0 . 3 \% )}$ \\
\hline Previous artificial abortion (yes/no) & $3 / 5 / 1$ \\
\hline Previous congenital anomalies in the family (yes/no) & $6 / 87$ (6.5\%/93.5\%) \\
\hline
\end{tabular}

Table 1. Characteristics of the pregnant women who responded to the questionnaire. 
Reason for taking medication during pregnancy (hypertension/uterine contractions/common cold/anaemia/asthma/hormonal substitution/pain/antibiotic prophylaxis after amniocentesis/more than two reasons/no clear reason) $(\mathrm{n}=50)$

Who advised or prescribed the medication (doctor/a friend/own decision) $(\mathrm{n}=50)$

$2 / 12 / 9 / 3 / 3 / 3 / 3 / 3 / 4 / 8$

$(4 \% / 24 \% / 18 \% / 6 \% / 6 \% / 6 \% / 6 \% / 6 \% / 8 \% / 16 \%)$

Compliant with therapy regimen (yes/no) $(n=50)$

$46 / 1 / 3(92 \% / 2 \% / 6 \%$

Gynaecological disorder (yes/no) (n=93)

Using vaginal preparation with St John's wort during pregnancy $(\mathrm{n}=93)$

$46 / 4(92 \% / 8 \%)$

$6 / 87(7 \% / 93 \%)$

Using "natural" (herbal) drugs during pregnancy (no/honey-based preparations/herbal tea) (n=93)

Using vitamins during pregnancy (no/hydrosoluble vitamins/liposoluble vitamins/

multivitamin preparations) $(\mathrm{n}=93)$

$18 / 75(19 \% / 81 \%)$

$66 / 4 / 23(71 \% / 4 \% / 25 \%)$

$26 / 22 / 4 / 41(28 \% / 24 \% / 4 \% / 44 \%)$

Experiencing side effects of medication during pregnancy (yes/no) (n=93)

3/90 (gastrointestinal complaints or rash) (3\%/97\%)

Source of information about pregnancy (Internet/TV/books/pregnancy counselling centre/ 6 6/8/1/3/2/73

other/multiple sources) ( $\mathrm{n}=93)$

$(6.5 \% / 8.6 \% / 1.1 \% / 3.2 \% / 2.2 \% / 78.5 \%)$

Source of information about the Facebook profile (notice on the Facebook profile/recommended by a friend or relative/counselling service/other) $(n=93)$

Receiving antibiotics during pregnancy (yes/no) (n=93)

$19 / 53 / 8 / 13$

$(20.4 \% / 57 \% / 8.6 \% / 14 \%)$

Receiving antihypertensive therapy during pregnancy (yes/no) (n=93)

$18 / 75(19.4 \% / 80.6 \%)$

Receiving anxiolytics during pregnancy (yes/no) $(\mathrm{n}=93)$

$6 / 87(6.5 \% / 93.5 \%)$

Receiving sex hormones during pregnancy (yes/no) (n=93)

$2 / 91(2.2 \% / 97.8 \%)$

Receiving tocolytics during pregnancy (yes/no) (n=93)

$10 / 83(10.8 \% / 89.2 \%)$

Receiving multivitamins during pregnancy (yes/no) (n=93)

$13 / 80(14 \% / 86 \%)$

Receiving multivitamins during pregnancy (yes/no) (n=93)

$41 / 52(44.1 \% / 55.9 \%)$

Receiving minerals during pregnancy (yes/no) $(\mathrm{n}=93)$

$20 / 73(21.5 \% / 78.5 \%)$

Receiving analgesics during pregnancy (yes/no) $(\mathrm{n}=93)$

9/84 $(9.7 \% / 90.3 \%)$

Receiving folic acid during pregnancy (yes/no) (n=93)

$23 / 70(24.7 \% / 75.3 \%)$

Receiving drugs for anaemia during pregnancy (yes/no) (n=93)

Receiving antiepileptics during pregnancy (yes/no) (n=93)

Availability of counselling service (yes/no) $(n=93)$

Visiting counselling service (yes/no) $(n=93)$

$4 / 89(4.3 \% / 95.7 \%)$

$1 / 92(1.1 \% / 98.9 \%)$

$83 / 10(89.2 \% / 10.8 \%)$

$56 / 37(60.2 \% / 39.8 \%)$

Table 2. Characteristics of the medications and therapeutic regimens used by the pregnant women who responded to the questionnaire.

\begin{tabular}{|c|c|c|c|}
\hline $\begin{array}{l}\text { DRUG AND MODE OF } \\
\text { ADMINISTRATION }\end{array}$ & $\begin{array}{l}\text { NUMBER OF PREGNANT } \\
\text { WOMEN USING THE DRUG }\end{array}$ & INDICATION & JUSTIFICATION \\
\hline Amoxicillin, oral & $6(6.4 \%)$ & Common cold & Unjustified \\
\hline Cephalexin, oral & $4(4.3 \%)$ & Common cold & Unjustified \\
\hline Erythromycin, oral & $3(3.2 \%)$ & Common cold & Unjustified \\
\hline Amoxicillin, oral & $2(2.1 \%)$ & $\begin{array}{l}\text { Antibiotic prophylaxis after } \\
\text { amniocentesis }\end{array}$ & Justified \\
\hline Progesterone, parenteral & $8(8.6 \%)$ & Threatening abortion & Unjustified \\
\hline Diazepam, oral & $2(2.1 \%)$ & Nervousness & Unjustified \\
\hline Folic acid, oral & $23(24.7 \%)$ & Supplementation & Justified \\
\hline $\begin{array}{l}\text { Multivitamin and multi-mineral preparations } \\
\text { with recommended daily intake } \\
\text { of vitamins and minerals, oral }\end{array}$ & $32(34.4 \%)$ & Supplementation & Unjustified \\
\hline Iron, oral & $12(12.9 \%)$ & Anaemia & Justified \\
\hline Tocolytic drugs (beta2 agonists), oral & $12(12.9 \%)$ & Premature contractions of uterus & Justified \\
\hline Methyldopa, oral & $4(4.3 \%)$ & Hypertension in pregnancy & Justified \\
\hline Nystatin + nitrofurantoin, vaginal & $4(4.3 \%)$ & Vaginal infection & Justified \\
\hline
\end{tabular}

Table 3. Justification of drug use during pregnancy in patients who participated in this survey. 
Our study did not attempt to advise pregnant women because our group is not part of the health care system in Serbia, and legislation does not allow students to practice medicine, especially over social networks. Instead, we directed followers of our profile to official health care facilities that offer advice about drugs in pregnancy. However, none of the study participants followed this advice and went to an official facility. This study concludes that using Internet-based social networks may help to address certain health issues (such as inappropriate drug use in pregnancy) that cannot be addressed in official ways. This conclusion has been previously identified for other patient groups $[1,13]$, but pregnant women are a particularly vulnerable group, and they may have difficulty visiting physicians.

There is also an issue about herbal drugs, which are frequently considered "safe" by patients without medical education [14]. As reported in a recent study, more than $50 \%$ of the pregnant women in Norway used herbal remedies during pregnancy, [14]. In our study, fewer pregnant women used herbal remedies (29\%), but this number was almost one-third of the study sample. Because herbal remedies have received less investigation than registered drugs and their safety profiles have not been established with certainty [15], it is important to educate pregnant women about the possible risks of these remedies. A Facebook profile such as the one used in this study could be very useful for disseminating important information about herbal drug use in pregnancy.

Our results suggest that a Facebook profile devoted to drug use in pregnancy could be a useful adjunct to efforts by official health care institutions to educate pregnant women about potentially harmful drug use.

\section{ACKNOWLEDGEMENTS}

This study was partially financed by grant No 175007 by the Serbian Ministry of Education. We confirm that all patient/personal identifiers have been removed or disguised so that the patient/person(s) described are not identifiable through the details of the study.

\section{REFERENCES}

1. Greene JA, Choudhry NK, Kilabuk E, Shrank WH. Online social networking by patients with diabetes: a qualitative evaluation of communication with Facebook. J Gen Intern Med 2011; 26: 287-92.
2. Rozental TD, George TM, Chacko AT. Social networking among upper extremity patients. J Hand Surg Am 2010; 35: 819-823.

3. Lord S, Brevard J, Budman S. Connecting to young adults: an online social network survey of beliefs and attitudes associated with prescription opioid misuse among college students. Subst Use Misuse 2011; 46: 66-76.

4. Knezevic MZ, Bivolarevic IC, Peric TS, Jankovic SM. Using Facebook to increase spontaneous reporting of adverse drug reactions. Drug Saf 2011; 34: 351-2.

5. McKenna L, McIntyre $M$. What over-the-counter preparations are pregnant women taking? A literature review. J Adv Nurs 2006; 56: 636-45.

6. Mashayekhi SO, Dilmaghanizadeh M, Fardiazar Z, Bamdad-Moghadam R, Ghandforoush-Sattari F. Study of awareness among pregnant women of the effects of drugs on the fetus and mother in Iran. Health Policy 2009; 91: 89-93.

7. Wahabi HA, Abed Althagafi NF, Elawad M, Al Zeidan RA. Progestogen for treating threatened miscarriage. Cochrane Database Syst Rev 2011; (3): CD005943.

8. Lammer EJ, Cordero JF. Exogenous sex hormone exposure and the risk for major malformations. JAMA 1986; 255: 3128-32.

9. Dal Pizzol Tda S, Sanseverino MT, Mengue SS. Exposure to misoprostol and hormones during pregnancy and risk of congenital anomalies. Cad Saude Publica 2008; 24 : 1447-53.

10. Leppée M, Culig J, Eric M, Sijanovic S. The effects of benzodiazepines in pregnancy. Acta Neurol Belg 2010; 110: 163-7.

11. Kjaer D, Horvath-Puhó E, Christensen J, Vestergaard M, Czeizel AE, Sørensen HT, Olsen J. Use of phenytoin, phenobarbital, or diazepam during pregnancy and risk of congenital abnormalities: a case-time-control study. Pharmacoepidemiol Drug Saf 2007; 16: 181-8.

12. Ryan-Harshman M, Aldoori W. Folic acid and prevention of neural tube defects. Can Fam Physician 2008; 54: 36-8

13. Bender JL, Jimenez-Marroquin MC, Jadad AR. Seeking support on facebook: a content analysis of breast cancer groups. J Med Internet Res 2011;13(1) :e16.

14. Holst L, Wright D, Haavik S, Nordeng H. The use and the user of herbal remedies during pregnancy. J Altern Complement Med 2009; 15: 787-92.

15. Ko RJ. A U.S. perspective on the adverse reactions from traditional Chinese medicines. J Chin Med Assoc 2004; 67: 109-16. 